\title{
ДОСЛІДЖЕННЯ ЕФЕКТИВНОСТІ РОБОТИ ІНВЕРТОРА ЦЕНТРАЛЬНОГО ТИПУ НА ПРОМИСЛОВІЙ СОНЯЧНІЙ ЕЛЕКТРОСТАНЦЇ̈
}

\author{
М.М. Бордаков, аспірант \\ Інститут відновлюваної енергетики НАН України \\ 02094, вул. Гната Хоткевича, 20А, м. Київ
}

При розрахунку сонячної електростанції ефективність інверторів приймається відповідно до наданої виробником кривої ефективності. Даний розрахунок зазвичай проводиться в програмному забезпеченні PV Syst. Виробник інвертора надає спеціальний файл, в якому зібрані всі технічні характеристики інвертора. Дана стаття досліджує ефективність інвертора в реальних умовах роботи. Зі вступом в силу закону про ринок електричної енергії власники промислових СЕС мають передавати прогноз роботи СЕС. При розробиі моделі прогнозування використовується ефективність роботи всіх компонентів СЕС. Якщо, в реальних умовах ефективність роботи відрізняється від заявленої виробником, то точність прогнозу зменшується. Тому, перед початком розробки моделі прогнозування роботи СЕС потрібно дослідити ефективність роботи всіх ї̈ складових. Однією з основних складових СЕС є інвертор. Ефективність його роботи залежить від таких факторів: напруги на сонячних панелях, струму з ФЕМ, напруги в мережі видачі потужності, системи охолодження та внутрішньої конструкиї інвертора. В даній роботі обрана ФЕС, де всі інвертори мають однакову кількість конфігураиій сонячних панелей.

При проведенні дослідження було оброблено хвилинні дані роботи кожного інвертора за період вересень 2018 р по червень 2019. За кожен день роботи було обраховано ефективність роботи інверторів. В подальшому, дані з дослідження будуть використані в прогнозуванні роботи даної ФЕС. Бібл. 10, рис. 6.

Ключові слова: ефективність роботи, сонячна електростанція, навантаження, напруга, інвертор, струм.

\section{INVESTIGATION OF THE EFFICIENCY OF OPERATION OF A CENTRAL TYPE INVERTER AT AN INDUSTRIAL SOLAR POWER PLANT}

\author{
M. Bordakov, postgraduate student \\ Institute of Renewable Energy of the National Academy of Sciences of Ukraine \\ 02094, 20A Hnata Khotkevycha Str., Kyiv.
}

When calculating a solar power plant, the efficiency of the inverters is taken in accordance with the efficiency curve provided by the manufacturer. This calculation is usually done in PV Syst software. The inverter manufacturer provides a special file that contains all the inverter specifications. This article examines the inverter's performance under real-world operating conditions. With the entry into force of the Law on the Electricity Market, the owners of industrial SES must submit a forecast of SES operation. The development of the forecasting model uses the efficiency of all components of the SES. As in the real world, the performance is different from that stated by the manufacture, the accuracy of the forecast is reduced. Therefore, before starting the development of the model of forecasting of the SES, it is necessary to examine the efficiency of all its components. One of the main components of the SES is the inverter. The efficiency of its operation depends on the following factors: voltage on solar panels, current from the PV, voltage in the power supply network, cooling system, and the internal design of the inverter. In this work, FES is selected where all inverters have the same number of solar panel configurations.

During the study, the minute data of the operation of each inverter for the period September 2018 to June 2019. Were processed. In the future, the data from the study will be used to predict the operation of this FES. Ref. 10, fig. 6.

Keywords: efficiency, solar power, load, voltage, inverter, current.

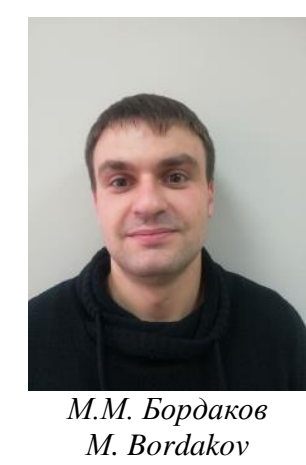

Відомості про автора: аспірант IBE НАН України.

Освіта: В 2016 р. закічив НТУУ “КПІ” ім. Сікорського за спеціальністю електротехніка та електротехнології. Отрима ступінь: молодшого інфженера-дослідника. 32016 аспірант IBE НАН України.

Наукова сфера: сонячна енергетика, апаратна частина інвертора для сонячних панелей.

Публікації: 3.

ORCID: 0000-0002-2890-5632

Контакти: тел.: +380935669447

e-mail: m.m.bordakov@gmail.com
Author information: postgraduate student Institute of Renewable Energy of the National Academy of Sciences of Ukraine.

Education: In 2016, the NTUU "KPI" im. Sikorsky specialty: electrical engineering and electrotechnology. Get a degree: junior research engineer.

Research area: solar energy, hardware part of solar panel inverter.

Publications: 3 .

ORCID: 0000-0002-2890-5632

Contacts: tel.: +3809356 69447

e-mail: m.m.bordakov@gmail.com 
Перелік використаних позначень та скорочень:

СЕС - сонячна електростанція;

ВДЕ - відновлювані джерела енергії;

Вступ. Зі вступом в силу закону про ринок електричної енергії, постало питання прогнозування роботи сонячних електростанцій на добу. Всі гравці ринку сонячної енергетики почали закупати чи розроблювати системи прогнозування для вже створених CЕС. Також, даний закон передбачає «зелені аукціони», які в подальшому формують ціну на купівлю гарантованим покупцем електроенергії, відпущеної з СЕС або 3 іншого джерела ВДЕ. Для створення прогнозу роботи сонячної електростанції потрібно оцінити ії ефективність на всіх етапах перетворення та передачі енергії. Детально ця інформація подана в міжнародному стан-
ФЕС - фотоелектрична станція;

ФЕМ - фотоелектричний модуль.

дарті: IEC TS 61724 [1]. Одним з таких параметрів $\epsilon$ ефективність роботи інверторів. Даний параметр також цікавий для вибору інверторів на нові проекти. Дана стаття присвячена дослідженню ефективності роботи інверторів на ФЕС потужністю 9 МВт.

Типи ефективності інверторів. Для оцінки ефективності вводять поняття кривої ефективності [2]. Крива ефективності показуе графік зміни ефективності роботи інвертора в залежності від вхідної потужності та напруги на сонячних модулях. Кожен виробник інверторів в своїй технічній інформації надає дану криву. Приклад кривої ефективності надано на рис. 1.

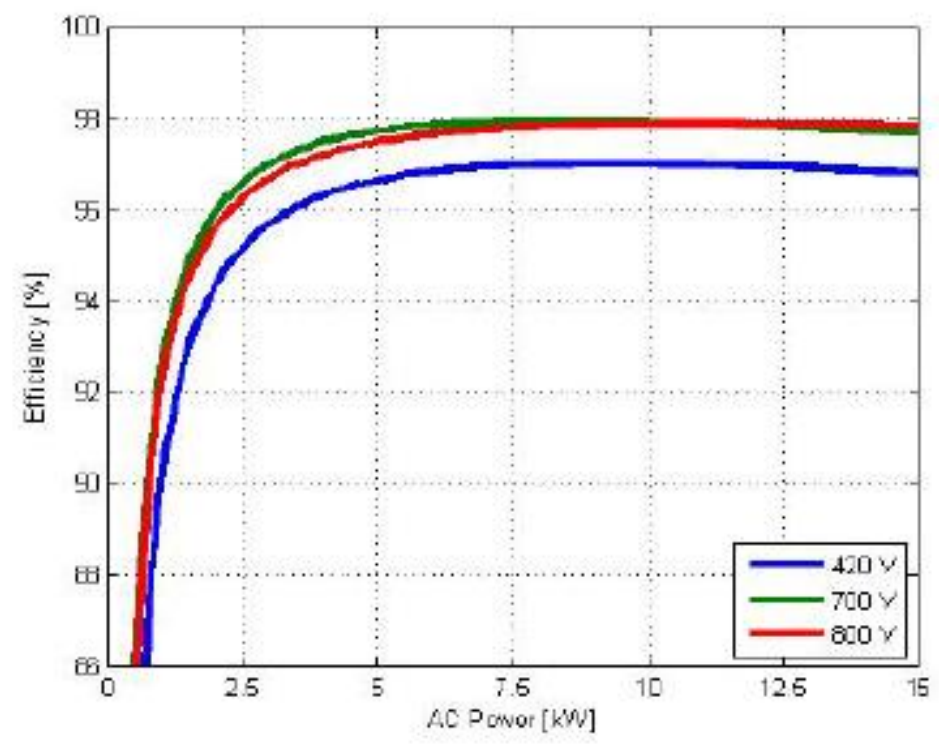

Рис. 1. Приклад кривої ефективності.

Fig. 1. Example of eff curve.

3 графіків на рис. 1 можна зробити висновок, проте що ефективність $€$ не постійною та має залежність від вихідної потужності. Тому для іiі оцінки в літературі вводять два параметра: Євро ефективність $\left(\eta_{\text {euro }}\right)$ та Максимальна ефективність $\left(\eta_{\max }\right)$. Максимальна ефективність максимально зафіксована ефективність при роботі інвертора або при його тестуванні. Свро ефективність - даний параметр враховує як інвертор працює на протязі всієї кривої завантаженості. Євро ефективність розраховується за формулою:

$$
\begin{gathered}
\eta_{\text {euro }}=0.03 \cdot \eta_{10 \%}+0.06 \cdot \eta_{20 \%}+0.13 \cdot \eta_{30 \%}+ \\
+0.1 \cdot \eta_{30 \%}+0.48 \cdot \eta_{50 \%}+0.48 \cdot \eta_{50 \%}+0.20 \cdot \eta_{100 \%},
\end{gathered}
$$

де $\eta_{10 \%}$ - середня ефективність роботи інвертора при навантаженнях від 0 до 10 \% від номінальної потужності; $\eta_{20 \%}$ - середня ефективність ро- боти інвертора при навантаженнях від 10 до $20 \%$ від номінальної потужності; $\eta_{30 \%}$ - середня ефективність роботи інвертора при навантаженнях від 20 до 30 \% від номінальної потужності; $\eta_{50 \%}$ - середня ефективність роботи інвертора при навантаженнях від 30 до 50 \% від номінальної потужності; $\eta_{100 \%}$ - середня ефективність роботи інвертора при навантаженнях від 50 до 100 \% від номінальної потужності.

Збір інформації з СЕС для оцінки ефективності роботи інверторів. Відповідно до IEC TS 61 724-1 [1] потрібно зібрати похвилинні дані 3 пристроїв та датчиків, які знаходяться на ФЕС. В даній статті нас цікавлять дані 3 інверторів. 3 загального списку даних ми маємо взяти такі параметри: $P_{a c}$ та $P_{d c}$. $P_{a c}$ - вихідна потужність інвертора, $P_{d c}-$ вхідна потужність постійного 
струму в інвертор. По хвилинне значення має бути середнім за хвилину. 3 інвертора знімається покази 3 частотою 1 мс, далі значення усереднюється. Середнім значення і буде наше по хвилинне значення. Як що використати миттєві по хвилинні значення то буде зменшена точність вимірювання. Зміна в точності може сягати до 3$5 \%$. Для розрахунку відсотку завантаженості інвертора потрібна його номінальна потужність змінного струму $P_{n o m}$. Значення в яких $P_{a c}=0$ або $т$ та $P_{d c}=0$ не приймають участі в оцінці роботи. По хвилинні значення ефективності розраховуються за формулою:

$$
\eta_{x b .}=\frac{P_{a c}}{P_{d c}} \cdot 100 \% .
$$

Точки в яких ККД вищий за 100\% мать бути відкинуті. Дана ситуація можлива при низьких рівнях сонячної радіації. Зазвичай спостерігається на старті інвертора або ввечері коли інвертор завершує свою роботу. Завантаженість інвертора розраховується за формулою:

$$
\text { Load }=\frac{P_{a c}}{P_{\text {nom }}} \cdot 100 \%
$$

Після розрахунку данні усереднються за 15 хвилин відповідно до наведеного вище стандарту. 3 усереднених значень вибирається максимальне значення, яке i буде дорівнювати $\eta_{\max }$. Далі виділяємо області значень які потрібні для розрахунку $\eta_{\text {euro }}$. Після цього проводимо розрахунок за формулою (1). За описаним вище алгоритмом розраховуємо ефективності за кожну добу роботи ФЕС.

Оцінка ефективності роботи інверторів СЕС. Для попередньої оцінки роботи інверторів будуємо дві криві ефективності за одну добу. Перша крива відображає по хвилинні значення роботи інвертора, друга - усереднені 15 хвилинні значення. Номінальна потужність інверторів даної ФЕС 550 кВт. На рис. 2 зображено криву ефективності роботу одного інвертора за одну добу.

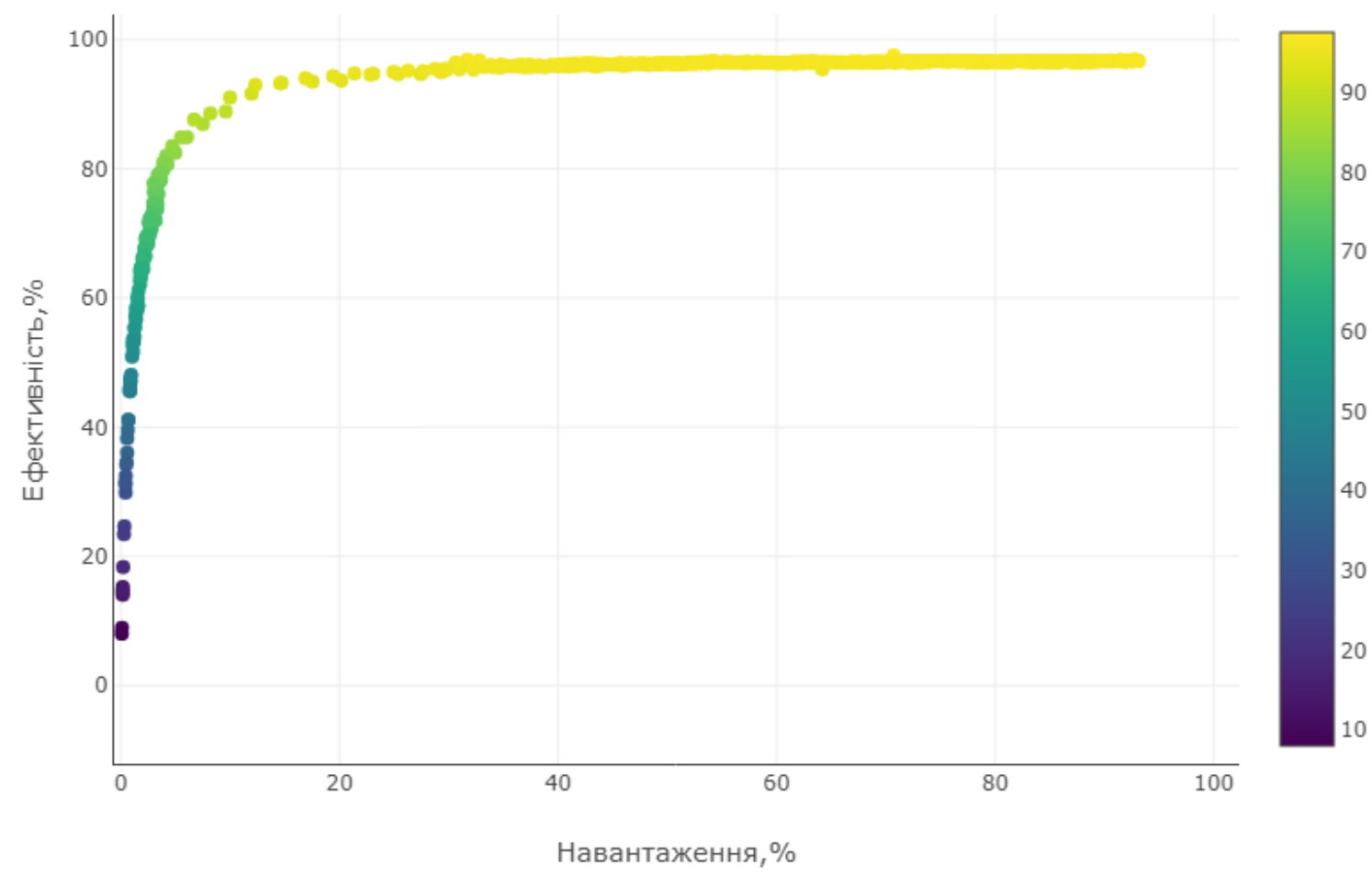

Рис. 2. Крива ефективності роботи одного з інверторів.

Fig. 2. Performance curve of one of the inverters.

На графіку, що зображено на рис. 2 різним кольором, виділені області, які потрібні для розрахунку євро ефективності. На рис. 3 наведено криву ефективності даного інвертора усереднену за 15 хв. На даній кривій вже виділено області для розрахунку євро ефективності. Для даної доби максимальна ефективність $\eta_{\max }=92,74 \%$. Свро ефективність $\eta_{\text {euro }}=91,5 \%$.
На досліджувані ФЕС встановлено 18 інверторів потужністю 550 кВт. На кожен інвертор підключена однакова потужність сонячних панелей 637 кВт. Для оцінки їх роботи вибрано період 3 жовтня 2018 по червень 2019. За кожен день даного періоду обраховуємо ефективнисть роботи. Для даної статті були використані дані за 285 днів. 


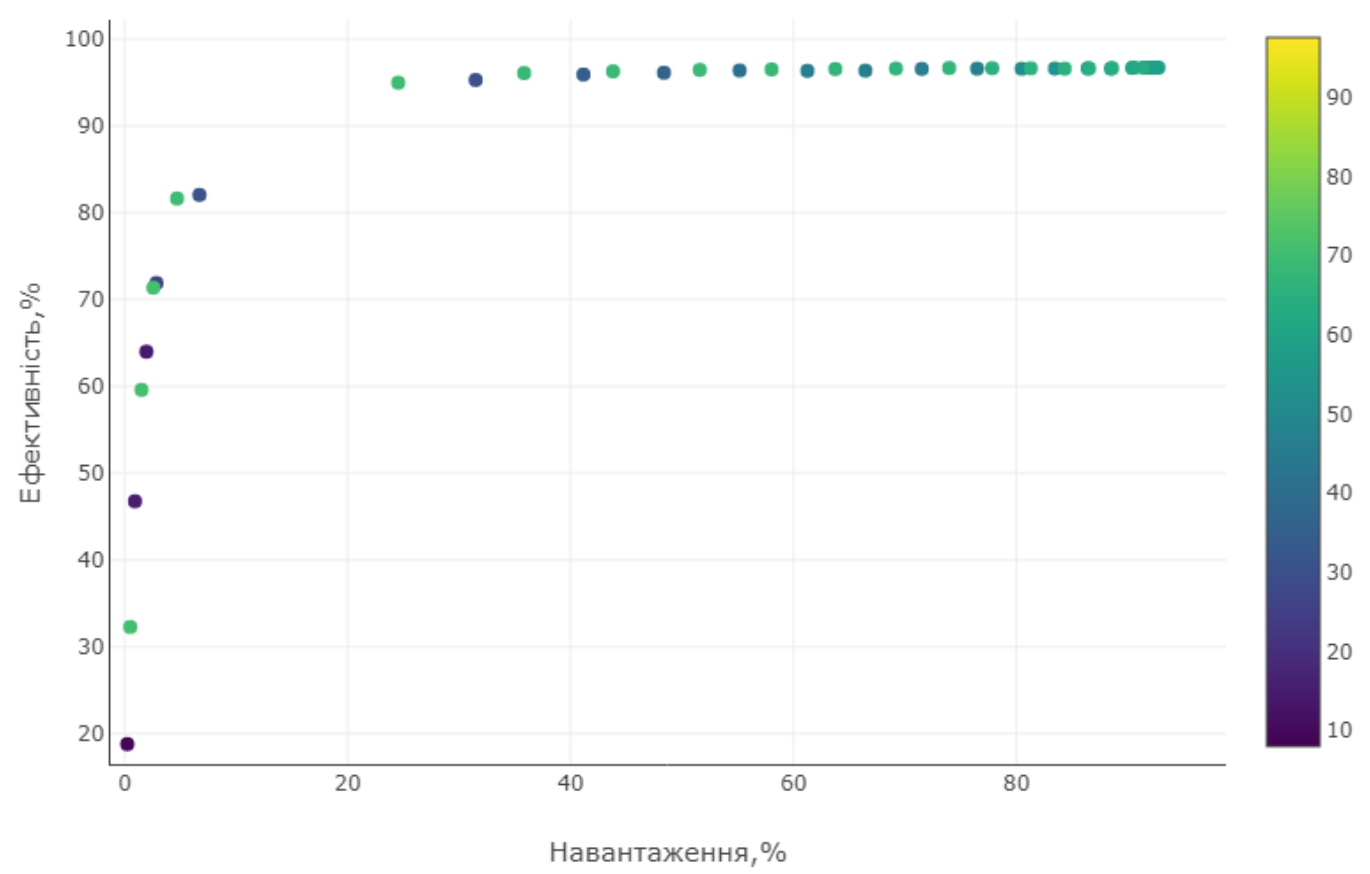

Рис. 3. Ефективність роботи інвертора 15 хвилинні значення.

Fig. 3. The efficiency of the inverter, using 15 minute values.

При розрахунку є дати, в яких завантаженість інвертора не перевищувала 30 \%. Ці дати зустрічаються в зимовий час та в дні з низькою сонячною інсоляцією. Свро ефективність для них порахувати не можливо. Євро ефективність для них приймається як відсутня. На рис. 4 зображено розподіли євро ефективностей по інверторам з період спостереження. Проаналізувавши даний розподіл можна зробити такі висновки:
1. Навіть в розрізі однієї станції однакові інвертори з однаковою кількістю панелей на вході мають різну ефективність.

2. Реальна євро ефективність відрізняється від заявленої виробником в середньому на 3-4\%. Заявлена євро ефективність 98.5\%.

3. Різниця в євро ефективності між інверторами становить від $1,5 \%$ до 2,5\%.

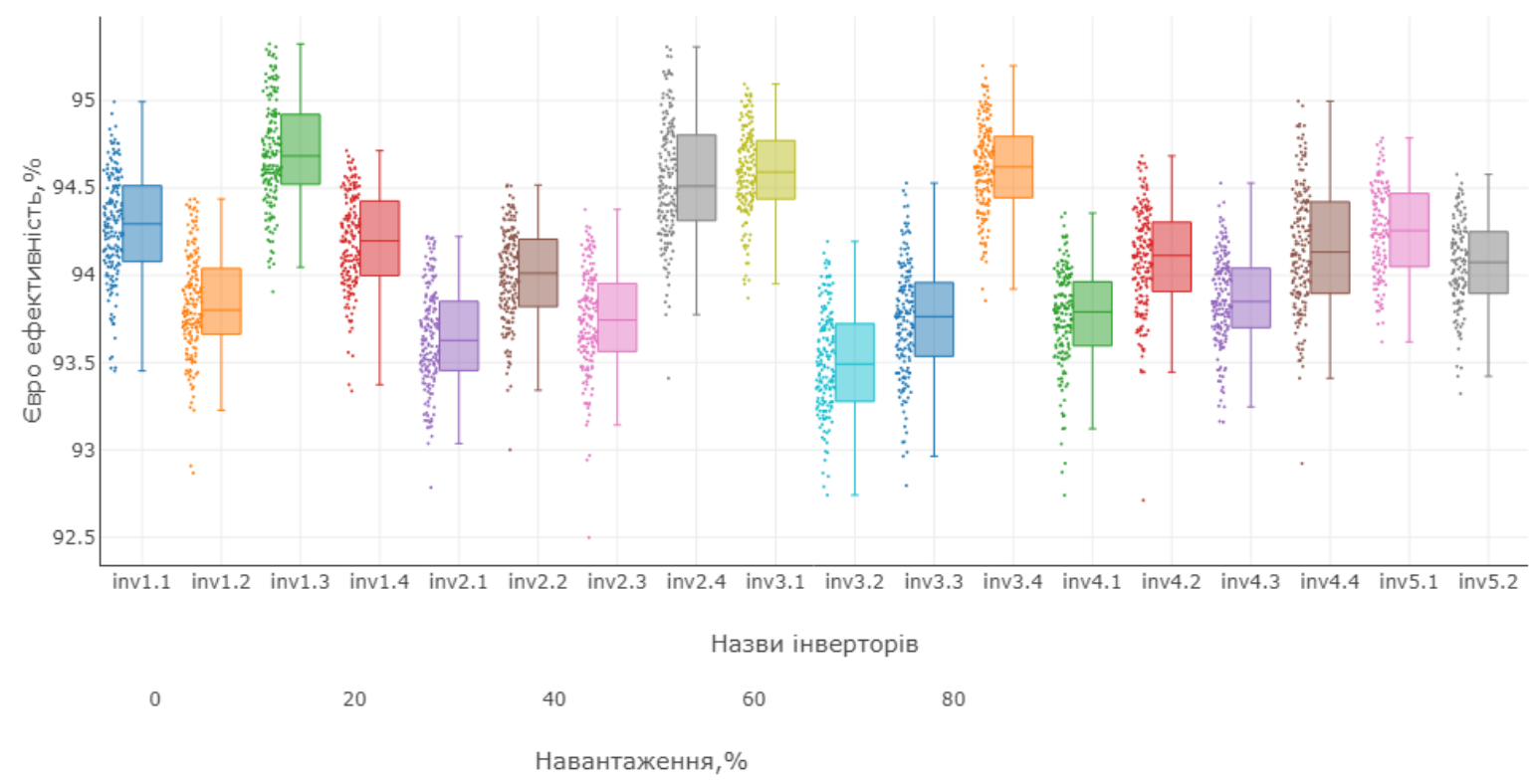

Рис. 4. Розподіл свро ефективності між інверторами за період спостереження.

Fig. 4. Distribution of Euro efficiency between inverters during the observation period. 
При аналізі рис. 4 потрібно розуміти, що номер інвертора складається 3 двох цифр: перша цифра - номер інверторної станції в якій встановлено інвертор, друга цифра - номер інвертора в інверторній станції. Для оцінки повної картини ефективності роботи інверторів ФЕС доцільно дослідити розподіл середнього значення євро ефективності між інверторами.
На рис. 5 зображено розподіл євро ефективності загалом по ФЕС. 3 даного розподілу робимо висновок, що інвертори на досліджуваній ФЕС працюють 3 середнім показником євро ефективності $94.5 \%$, що в порівнянні з паспортним значенням на $4 \%$ менше. Тобто, дана ФЕС генерує на $4 \%$ енергії менше ніж могла, як би інвертор забезпечував паспортний рівень євро ефективності.

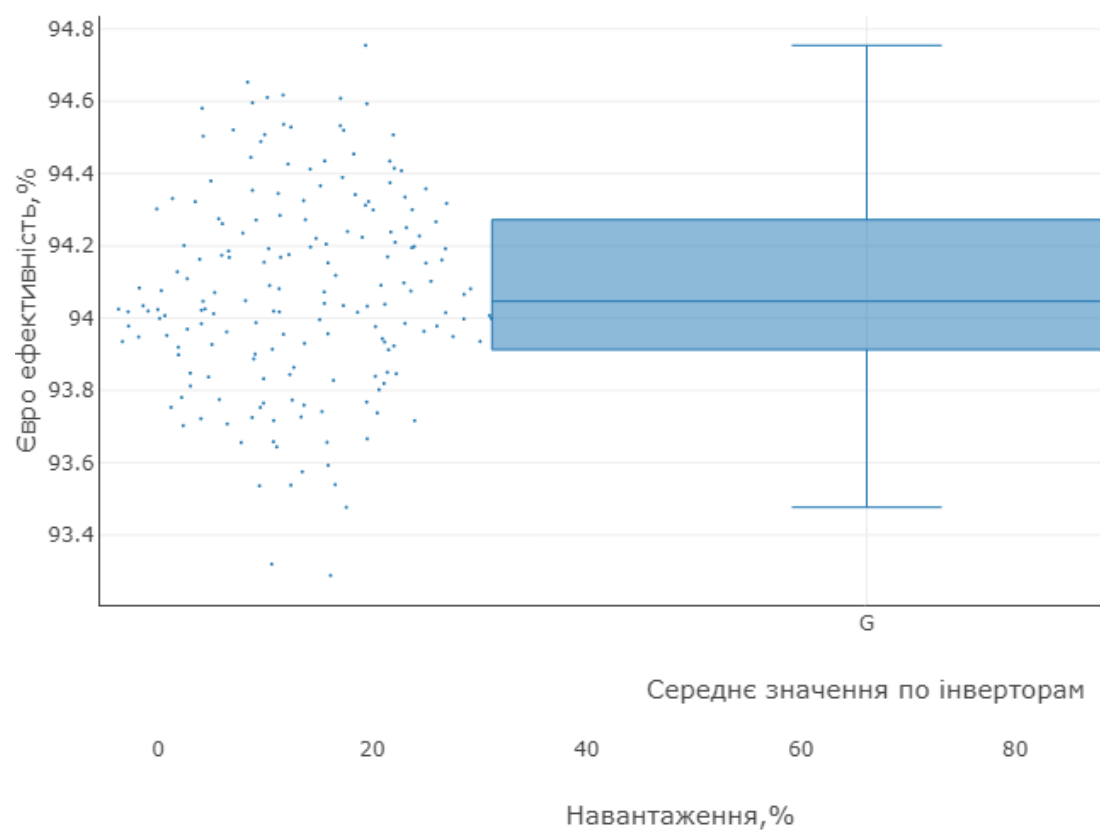

Рис. 5. Розподіл середнього значення євро ефективності за період спостереження загально по ФЕС.

Fig. 5. Distribution of the average value euro efficiency over the observation period in the total PV farm.

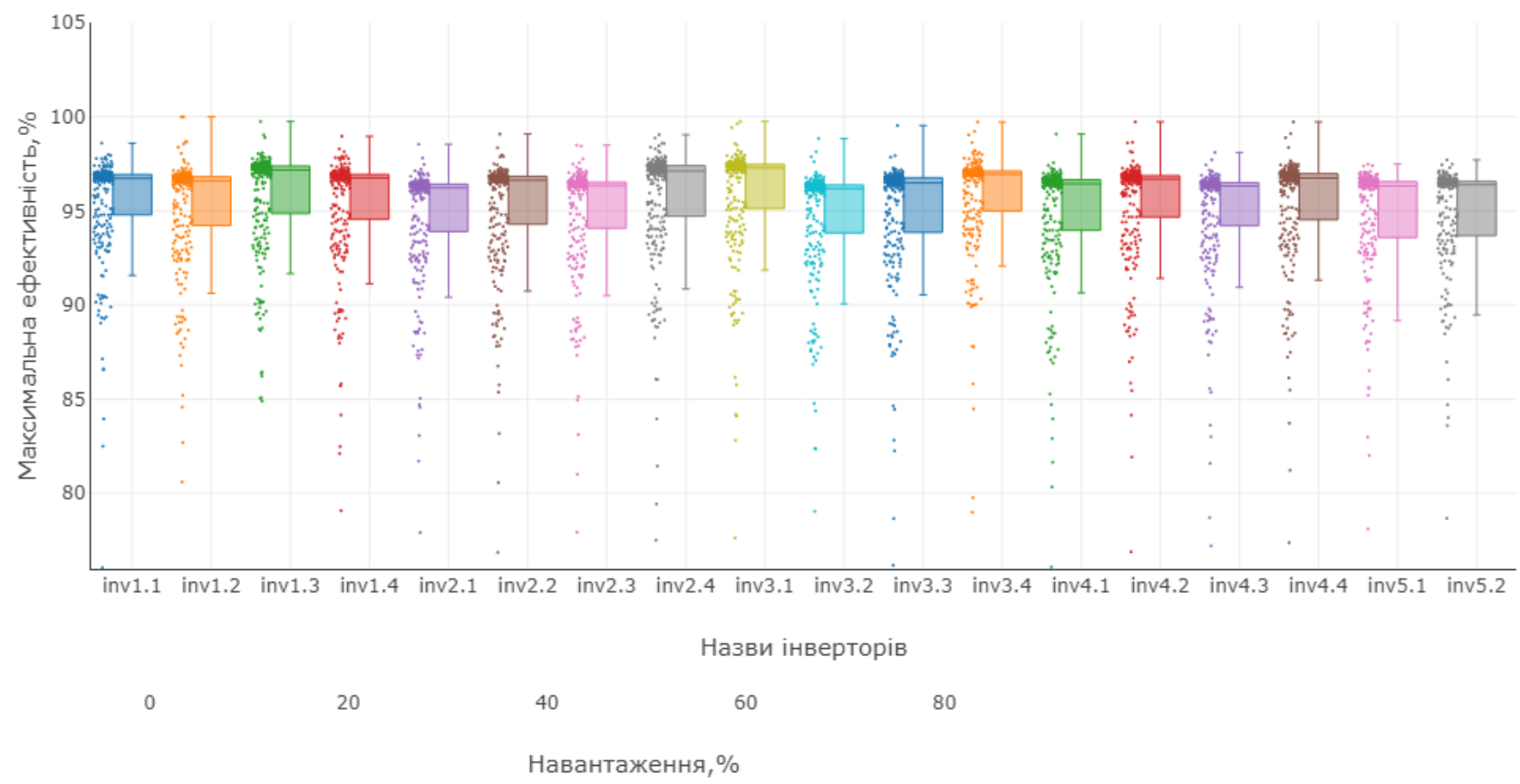

Рис. 6. Розподіл максимальної ефективності по інверторам.

Fig. 6. Maximum efficiency distribution by inverters. 
3 розподілу зображеного на рис.6 можна зробити такі висновки:

1. В деякі дні максимальна ефективність досягає паспортних значень: 98,9\%.

2. В середньому максимальна ефективність інверторів даної ФЕС знаходиться на рівні 96,1%.

Висновки. Перш за все потрібно пояснити відхилення реальних параметрів від паспортних значень. Причинами перш за все можуть бути такі фактори:

1. Напруга на ФЕМ;

2. Напруга в мережі змінного струму;

3. Підвищена частота мережі;

4. Температура інвертора.

Варіант 3 температурою виключаємо, адже на даній ФЕС зменшення потужності через перегрів не були зафіксованими. Основними причинами $є$ напруга мережі та напргуга на ФЕМ.

Під час аналізу ефективності роботи інверторів на даній ФЕС виявлено те, що інвертори мають відмінності в ефективності роботи між собою. Дана ситуація можлива через локальні відмінності між інверторами.

1. Постанова НКРЕКП №312 від 14.03.2018. [Електронний ресурc]. URL: http://www.nerc.gov.ua/?id=31833.

2. ДСТУ 8635:2016. Площадки для фотоелектричних станцій приєднання станцій до електроенергетичної системи. [Електронний ресурc]. URL: http://eom.com.ua/ index.php?action $=$ downloads;sa $=$ downfile $\&$ id $=3656$.

3. Reactive Power Interconnection Requirements for PV and Wind Plants-Recommendations to NERC. [Електронний pecypc]. URL: https://prod-ng.sandia.gov/techlib-noauth/accesscontrol.cgi/2012/121098.pdf.

4. Brown T. Transmission network loading in Europe with high shares of renewables. IET Renewable Power Generation. 2015. vol. 9. no. 1. Pp. 57-65.

5. GB/T19964-2012. Photovoltaic power plant power system access technical requirements. Beijing: General Administration of Quality Supervision, Inspection and Quarantine of People's Republic of China. China National Standardization Management Committee. 2012.

6. Campbell M., Aschenbrenner P., Blunden J., Smeloff E., Wright $S$. The drivers of the levelized cost of electricity for utility-scale photovoltaics. SunPower Corp. 200.

7. Zhou J., Gole A. VSC transmission limitations imposed by AC system strength and AC impedance characteristics. Proc. 10th IET International Conference on AC and DC Power Transmission (ACDC). 2012. Pp. 1-6.

8. Collins L., Ward J. Real and reactive power control of distributed PV inverters for overvoltage prevention and increased renewable generation hosting capacity. Renewable Energy. 2015. vol. 81. Pp. 464-471.

9. Utility-scale solar photovoltaic power pants-A project developer's guide. International Finance Corporation (IFC). 2015.

10. Molina-Garcia A., Mastromauro R.A., Garcia-Sanchez T., Pugliese S., Liserre M., Stasi S. Reactive power flow control for PV inverters voltage support in LV distribution networks. IEEE Trans. Smart Grid. 2017. vol. 8. no. 1. Pp. 447-456.

\section{REFERENCES}

1. Postanova NKREKP №312 vid 14.03.2018. [NERCP Resolution № 312 dated March 14, 2018]. [Electronic resource]. URL: http://www.nerc.gov.ua/?id=31833. [in Ukrainian].

2. DSTU 8635:2016. Ploshchadky dlya fotoelektrychnykh stantsiy pryyednannya stantsiy do elektroenerhetychnoyi systemy. [DSTU 8635: 2016 "Surfaces for photoelectric stations connection of stations to the electrical energy system"]. [Electronic resource]. URL: http://eom.com.ua/index.php?action=downloads;sa=downfile\&id =3656. [in Ukrainian].

3. Reactive Power Interconnection Requirements for PV and Wind Plants-Recommendations to NERC. [Електронний pecypc]. URL: https://prod-ng.sandia.gov/techlibnoauth/access-control.cgi/2012/121098.pdf. [in English].

4. Brown T. Transmission network loading in Europe with high shares of renewables. IET Renewable Power Generation. 2015. vol. 9. no. 1. Pp. 57-65. [in English].

5. GB/T19964-2012. Photovoltaic power plant power system access technical requirements. Beijing: General Administration of Quality Supervision, Inspection and Quarantine of People's Republic of China. China National Standardization Management Committee. 2012. [in English].

6. Campbell M., Aschenbrenner P., Blunden J., Smeloff E., Wright $S$. The drivers of the levelized cost of electricity for utility-scale photovoltaics. SunPower Corp. 200. [in English].

7. Zhou J., Gole A. VSC transmission limitations imposed by AC system strength and AC impedance characteristics. Proc. 10th IET International Conference on AC and DC Power Transmission (ACDC). 2012. Pp. 1-6. [in English].

8. Collins L., Ward J. Real and reactive power control of distributed PV inverters for overvoltage prevention and increased renewable generation hosting capacity. Renewable Energy. 2015. vol. 81. Pp. 464-471. [in English].

9. Utility-scale solar photovoltaic power pants-A project developers guide. International Finance Corporation (IFC). 2015.

10. Molina-Garcia A., Mastromauro R.A., GarciaSanchez T., Pugliese S., Liserre M., Stasi S. Reactive power flow control for PV inverters voltage support in LV distribution networks. IEEE Trans. Smart Grid. 2017. vol. 8. no. 1. Pp. 447-456. [in English].

\section{ИССЛЕДОВАНИЕ ЭФФЕКТИВНОСТИ РАБОТЫ ИНВЕРТОРА ЦЕНТРАЛЬНОГО ТИПА НА ПРОМЫШЛЕННОЙ СОЛНЕЧНОЙ ЭЛЕКТРОСТАНЦИИ}

Н.Н. Бордаков, аспирант

Институт возобновляемой энергетики НАН Украины. 02094 ул. Гната Хоткевича, 20А, Киев

При расчете солнечной электростанции эффективность инверторов принимается в соответствии с предоставленной производителем кривой эффективности. Данный расчет обычно проводится в программном обеспечении $P V$ Syst. Производитель инвертора предоставляет специиальный файл, в котором собрань все технические характеристики инвертора. Данная статья исследует эффективность инвертора в реальных условиях работы. Со вступлением в силу закона о рынке электроэнергии, владельцыы промышленных СЭС должны передавать прогноз работы СЭС. При разработке модели прогнозирования используется эффек- 
тивность работь всех компонентов СЭС. Если в реальных условиях, эффективность работы отличается от заявленной производителем, то точность прогноза уменьшается. Поэтому, перед началом разработки модели прогнозирования работь СЭС нужно исследовать эффективность работы всех ее составляюших. Одной из основных составляюших СЭС является инвертор. Эффективность его работь зависит от следуюших факторов: напряжения на солнечных панелях, тока с ФЭМ, напряжения в сети выдачи мощности системы охлаждения и внутренней конструкции инвертора. $B$ данной ста- тье выбрана ФЭС где все инверторы имеют одинаковое количество конфигураций солнечных панелей.

При проведении исследования было обработано минутные данные работы каждого инвертора за период сентябрь 2018 2. по июнь 2019. За каждый день работы было подсчитано эффективность работь инверторов. В дальнейшем, данные по исследованию будут использованы в прогнозировании работы данной ФЭС. Библ. 10, рис. 6.

Ключевые слова: эффективность работы, солнечная электростанциия, нагрузка, напряжение, инвертор, ток.

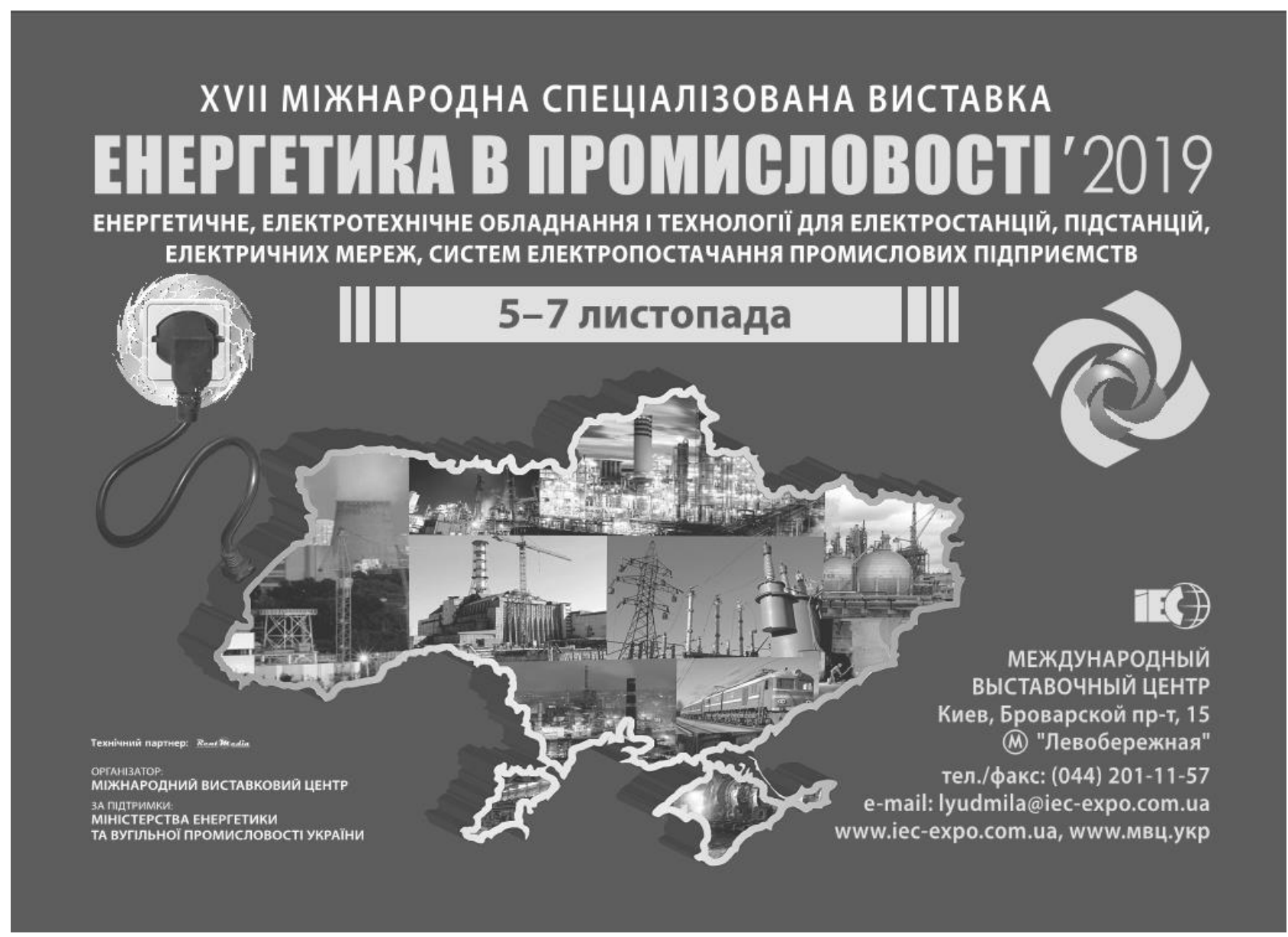

